\title{
Nucleus of Diagonal Band
}

National Cancer Institute

\section{Source}

National Cancer Institute. Nucleus of Diagonal Band. NCI Thesaurus. Code C97342.

A brain structure that is part of the septal nuclear complex. It is connected with the hippocampus, hypothalamus and amyg dala. 